\title{
Muuseumid tänapäeval: väljakutsed ja võimalused
}

Pille Runnel

Käesolev kogumik koondab artikleid muuseumi- ja pärandiuuringute valdkonnast. Kesksel kohal on originaaluurimused, mis põhinevad Eesti muuseumide tegevuse analüüsil. Nende juhtumiuuringute väärtus seisneb võrdselt nii muuseumide praktilise tegevuse toetamises kui ka dialoogis muuseumiuuringute valdkonna debattide ja uurimisküsimustega. Originaalartiklite osa on laiendatud valiku tõlkeartiklitega, eesmärgiga teha Eesti lugejaskonnale kättesaadavaks ja tõsta esile praegu rahvusvaheliselt 
olulisi küsimusi muuseumiinstitutsiooni, muuseumide rolli ja muuseumide kommunikatsiooni valdkonnas.

Esimene teemaplokk käsitleb muuseumide suhteid külastajate ja auditooriumidega ning nende seoste uurimise võimalusi, mis tänapäeval ei piirdu mitte ainult muuseumi tulnud inimeste kogemuse, huvi ja teenustega rahulolu hindamise ja analüüsiga, vaid läbib kõiki muuseumitöö aspekte. Eesti muuseumidest lähtuvad originaaluurimused käsitlevad auditooriumide rolli näituseproduktsioonis ja kuraatorite ettekujutust auditooriumidest, samuti auditooriumide kaasamist muuseumi haridusprogrammide vahendusel. Kolmas artikkel pakub auditooriumiuuringutele teoreetilist tausta, kontekstualiseerides muuseumide kommunikatsiooni uurimist meedia- ja kommunikatsiooniuuringute valdkonna uuringutega.

ERMi publikatsioonides on järjepidevalt ilmunud käsitlusi külastaja- ja auditooriumiuuringutest ning Krista Lepiku, 
Reet Mägi ja Pille Pruulmann-Vengerfeldti artikkel jätkab selle valdkonna uurimistööd.

Uurimus analüüsib auditooriumide rolli

Tartu Ülikooli loodusmuuseumi uue püsiekspositsiooni loomisel. Kui varasemad artiklid on käsitlenud pigem institutsiooni kui terviku tasandit ja tegelenud kaasamisviiside otsimisega muuseumitöös (või mõnel juhul ka nende muuseumitöösse integreerimisega), on käesoleva uurimuse fookus auditooriumide ja kaasamisviiside spetsiifilisematel aspektidel: millised lähenemised kureerimistöös domineerivad, kuidas need tekivad ja mis neid suunavad. Teise juhtumiuuringu autor Hanna-Liis Kont vaatleb kiusuennetusega tegelevaid haridusprogramme Eesti kunstimuuseumides. Viimastel aastatel on muuseumid asunud aktiivselt panustama inimeste heaollu. Siia kuulub ka ühiskonnaelust kõrvale jäetud inimrühmade kaasamine ja panustamine nende vaimsesse ja füüsilisse tegevusse. Artiklis analüüsitav kiusuennetusprogramm oli välja töötatud üldhariduskoolide õpilaste jaoks ja artikkel 
uurib, kuidas õnnestus programmides ühendada kiusuennetust kunsti

vahendamisega. Tulemused on lubavad, sest eri valdkondade süntees tundides näis toimivat: samaaegselt oli võimalik käsitleda kunsti olemust, sotsiaalseid oskusi ja hoiakuid ja näis, et tegelikkuses need eesmärgid pigem toetasid üksteist. Kiusuennetustegevused tuleks muuseumis tugevamalt siduda muude strateegiliste eesmärkidega, et sellised algatused ei jääks vaid katsetuseks.

\section{Susan Andersoni teoreetiline} ülevaateartikkel külastaja- ja auditooriumiuuringute suundumustest muuseumides käsitleb uurimisfookuse muutumist. Kui kaua aega tegelesid külastajauuringud peamiselt muuseumisse füusiliselt kohale tulnutega, siis alates 1980. ja 1990. aastatest laienes külastajate uurimine ka neile, kes võiksid muuseumi tulla. Tänapäeval mõjutavad muuseumiauditooriumide uuringuid olulisel määral meedia ja internetiauditooriumide uuringud, kuid mitte alati ei käida nende 
uuringutega $n$-ö ühte jalga, tuginedes juba mõnevõrra aegunud teooriatele ja lähenemistele.

Uueks etapiks on digiajastu auditooriumiuuringud. Muuhulgas püütakse neis kasutada andmeid, mida saadakse vahendusseadmetelt, näiteks mobiiltelefonidelt, otsides parimaid lahendusi, kuidas nende abil salvestada külastajate liikumist muuseumis ja seda analüüsida. Samuti püütakse mõista ja mõõta online-tegevuste mõju. Anderson küsib artiklis, millised on selliste, digitaalsete auditooriumiuuringute suunas liikumise tagajärjed muuseumidele.

Teises teemaplokis on uurimused pärandi esitamisest, loomisest ja kasutamisest muuseumide kontekstis. Uurimusi täiendab teoreetiline artikkel vaikuse vormidest muuseumides - kogude, institutsiooni, näituste ja kommunikatsiooni tasandil.

Karin Leivategija teeb ülevaate originaalsete filmieksponaatide loomisest 
ja esitamisest Eesti Rahva Muuseumi püsinäitusel „Kohtumised“. Ajalooliselt on näitustel kasutatavad filmid ja loodud filmieksponaadid olnud tugevalt kureeritud ja vaatajale on jäetud vähe tõlgendusruumi. ERMi uues püsiekspositsioonis on muuseumikülastaja võimalused filmide tõlgendamisel oluliselt vabamad. Näituse filmieksponaadid uurivad ja annavad edasi kaasaegsete inimeste vaateid ja ideid; heidavad detailse pilgu erinevatesse protsessidesse ja töövõtetesse ning esitavad ka minevikku. Näiteks on loodud mitu dokumentaalsel või pärimuslikul ainesel põhinevat, arhiividokumente ja muuseumikogudes leiduvaid esemeid kasutavat lavastuslikku filmi. Autor küsib, kuidas saab näituse kureerimisprotsess ja filmi režii vähendada riski, et selliseid ajalookäsitlusi ei peetaks ajaloo tõetruuks esituseks?

Liisi Jäätsi artikkel asetub oma fookuselt materiaalse kultuuri uuringute konteksti. Ta võtab kokku Eesti Rahva 
Muuseumi esemekogude kasutamisega seotud küsimused, pidades silmas potentsiaalse kogude uurija ja kasutaja vaatenurka ja toob välja võimalikke ja vajalikke allikakriitika rakendamise kohti. Ese võib olla väärtuslik uurimisallikas, kuid uurimistöös tekib palju küsimusi seoses eseme kui allikaga nii üksiku eseme kirjeldamise ja analüüsi kui ka tervikliku muuseumikogu tasandil. Eesti Rahva Muuseumi kogude näitel vaatleb ta, kuidas kogudes olevad objektid ja materjalid, nagu välitööde päevikud, aruanded, fotod, aga ka esemekirjeldused ja terviklikud esemekogud peegeldavad oma ajastu teadusteoreetilisi seisukohti ja arusaamu sellest, mis on kogude kujunemist kõige enam mõjutanud uurimisvaldkonna - etnograafia/ etnoloogia ja Eesti Rahva Muuseumi ülesanne. Lisaks allika ja distsipliini kontekstile on esemeuurimuses oluline ka muuseumikontekst.

Kurmo Konsa ja Kaie Jeeseri artikkel käsitleb pärandi kui tulevikku suunatud sotsiaalse ja kultuurilise ressursiga, mille 
kõige olulisem funktsioon on selle panus tuleviku kavandamisse. Nad annavad artiklis pärandiuuringute poolse vaate muuseumidele, tuginedes analüüsis kolmele mõõtmele: pärandiobjektide ja ühiskonna ning pärandihaldusprotsesside mõõde. Artikkel esitab kontseptuaalse raami, mis võiks aidata paremini välja tuua seoseid pärandi ja muuseumide vahel, soovides seeläbi pakkuda lähtekohta pärandiuuringute ja museoloogiliste teoreetiliste mõistete seostamiseks ning praktilise pärandihalduse paremaks korraldamiseks.

Rhiannon Masoni ja Joanne Sayneri analüüs muuseumis esinevatest vaikusest mõtlemise viisidest asetub laiemasse mälu-uuringute konteksti, kus rõhutatakse vaikuse performatiivset ja produktiivset olemust mälestusprotsessides. Nad leiavad, et muuseumides vaikimise kontseptualiseerimiseks on vaja haarata erinevaid vaikuse „tüüpe“ ja „vorme“: vaikus ei ole alati üks ja sama, eriti ilmseks muudab selle muuseumikeskkonna keerukus. 
Vaikus ilmneb ka muuseumide üleselt ja muuseumide vahel, niisiis on vaikuse uurimine oluline ka laiemate mälu-uuringute alaste debattide kontekstis.

\section{Kogumiku viimane osa}

koondab artikleid, mis kritiseerivad muuseumivaldkonna praeguseid arengusuundi. Autorid peavad oluliseks suurendada muuseumide ühiskondlikku vastutust ja rolli, kuna nende hinnangul jääb see tarbimisühiskonna meelelahutuslike trendide tõttu kohati tagaplaanile. See debatt ei ole uudne, kuid on jätkuvalt äärmiselt oluline, kuna on selge, et muuseumidel on olemas nii vajalikud lähtekohad kui ka võime ühiskonnas praegusest märksa suurema rolli täitmiseks.

Rasmus Kask otsib oma uurimuses muusemide ühiskondlike mõjude määratlemise suundi, analüüsides viimase 15 aasta erialakirjanduses välja toodud muuseumide ja ühiskonna suhtemudeleid. Analüüsis joonistuvad välja kolm peamist mudelit või kategooriat: „avalik väärtus“, 
„ühiskondlik mõju“ ja „ühiskondlik muutus“. Need eristuvad üksteisest teoreetiliste aluste, sihtrühma määratluse, tegevussuundade ning mõjuindikaatorite kirjelduse poolest. Tulemustele tuginedes analüüsib ta Eesti Vabaõhumuuseumi maaarhitektuuri keskuse varasemaid arengukavasid ja arutleb selle üle, kuidas suunata uue arengukava loomise protsessi nii, et keskuse arengukava toetaks senisest suurema ühiskondliku mõju saavutamist.

Briti museoloogia praeguseid võtmeteemasid käsitlev Robert R. Janesi ja Richard Sandelli artikkel põhineb vaatel, et muuseumid on mõjuvõimas kogukond, mida praeguses ajas hoiab tagasi liigne keskendumine haridusele, meelelahutusele ja tarbimisele. Nad kritiseerivad, et muuseumid on muutunud uneskõndijateks, „kes on leppinud sellega, et sammuvad magades tuleviku poole“. Neile tundub, et praegune muuseum kui ostukeskus kujutab endast materialistliku maailmavaate umbteed, mille väsimatu keskendumine 
rahale, tarbimisele ja turuideoloogiale aina pisendab muuseumi kui sotsiaalse institutsiooni ja olulise ühiskondliku ressursi rolli. Nad soovivad aidata leida teid sellest pääsemiseks, otsides viise muuseumile omase mõjuvõimu rakendamiseks ühiskonda edasiviivate eesmärkide saavutamise teenistusse, käsitledes neid tegevusi muuseumiaktivismina. Muuseumiaktivism, millest räägitakse järjest enam ka muuseumivaldkonna juhtivatel konverentsidel, on seadnud eesmärgiks kutsuda muuseumides esile nii poliitilist, sotsiaalset kui ka keskkondlikku muutust.

Fiona Cameroni, Bob Hodge'i ja Juan Francisco Salazari artikkel, mis on pealkirjastatud manifestina, analüüsib muuseumide ja teaduskeskuste rolli kliimamuutustega võitlemisel. Oma näidetes tuginevad nad peamiselt Austraalia teadusagentuuri sidustamisprojektile „Kuum teadus, globaalsed kodanikud: muuseumisektori roll võitluses kliimamuutuste vastu“, mis käsitles 
loodusmuuseumide, teadusmuuseumide ja teaduskeskuste rolli ja tegevust

kliimavaldkonnas. Cameron esitab koos

kaasautoritega üheksa strateegilist ettepanekut muuseumirolli muutuste kohta, rõhutades kollektiivset tegevust, võrgustumist ja kriitilise informatsiooni kasutamist kliimamuutuse keerulise ja väga olulise teema käsitlemisel. 